\title{
Starch Origin and Thermal Processing Affect Starch Digestion in a Minipig Model of Pancreatic Exocrine Insufficiency
}

\author{
Anne Mößeler, ${ }^{1}$ Sandra Vagt, ${ }^{1}$ Martin Beyerbach, ${ }^{2}$ and Josef Kamphues ${ }^{1}$ \\ ${ }^{1}$ Institute for Animal Nutrition, University of Veterinary Medicine Hannover, Foundation, Bischofsholer Damm 15, \\ 30173 Hannover, Germany \\ ${ }^{2}$ Department for Biometry, Epidemiology, and Information Processing, University of Veterinary Medicine Hannover, \\ Foundation, Bünteweg 2, 30559 Hannover, Germany \\ Correspondence should be addressed to Anne Mößeler; anne.moesseler@tiho-hannover.de
}

Received 15 October 2014; Revised 21 January 2015; Accepted 22 January 2015

Academic Editor: Paul Enck

Copyright (C) 2015 Anne Mößeler et al. This is an open access article distributed under the Creative Commons Attribution License, which permits unrestricted use, distribution, and reproduction in any medium, provided the original work is properly cited.

\begin{abstract}
Although steatorrhea is the most obvious symptom of pancreatic exocrine insufficiency (PEI), enzymatic digestion of protein and starch is also impaired. Low praecaecal digestibility of starch causes a forced microbial fermentation accounting for energy losses and meteorism. To optimise dietetic measures, knowledge of praecaecal digestibility of starch is needed but such information from PEI patients is rare. Minipigs fitted with an ileocaecal fistula with $(n=3)$ or without $(n=3)$ pancreatic duct ligation (PL) were used to estimate the rate of praecaecal disappearance $(\mathrm{pcD})$ of starch. Different botanical sources of starch (rice, amaranth, potato, and pea) were fed either raw or cooked. In the controls (C), there was an almost complete pcD (>92\%) except for potato starch (61.5\%) which was significantly lower. In PL pcD of raw starch was significantly lower for all sources of starch except for amaranth (87.9\%). Thermal processing increased $\mathrm{pcD}$ in $\mathrm{PL}$, reaching values of $\mathrm{C}$ for starch from rice, potato, and pea. This study clearly underlines the need for precise specification of starch used for patients with specific dietetic needs like PEI. Data should be generated in suitable animal models or patients as tests in healthy individuals would not have given similar conclusions.
\end{abstract}

\section{Introduction}

The pancreatic duct ligated (PL) pig or minipig is an established model for studying pancreatic exocrine insufficiency (PEI) in humans and for obtaining information about effects of PEI on digestive processes and for optimising enzyme substitution therapy [1-5].

Coefficients of absorption for fat and protein over the total tract are much more decreased in the case of PEI than that of starch. Overall, the topic of carbohydrate malabsorption in the case of PEI has still to be quantified accurately $[6,7]$. Amylorrhea is not a typical symptom of patients with PEI as loss of pancreatic amylase causes only a mild malabsorption of carbohydrates $[8,9]$ due to extrapancreatic amylases and the very high activity of the microflora resulting in an almost complete compensative starch fermentation in the hindgut [10]. In PL-pigs with complete loss of exocrinal pancreatic function and without pancreatic enzyme substitution therapy, starch digestibility over the entire alimentary tract did not differ from values observed in healthy controls $[10,11]$. In human PEI patients, Ladas et al. [7] found a malabsorption rate of about 10 to $30 \%$ for complex carbohydrates estimated over the entire gastrointestinal tract, indicating that the capacity for carbohydrate fermentation in the human hindgut is less pronounced than in pigs. Analyses of stool samples are a feasible method for direct quantification of net carbohydrate malabsorption in human patients but have the disadvantage of not allowing any differentiation between enzymatically and fermentative digestion of starch. Indirect parameters like hydrogen exhalation [12] enable estimation of the extent of bacterial fermentation in digestive processes of carbohydrates. In experimental studies, the use of fistulated animals enables the sampling of the ileal chyme, an interesting method to differentiate between digestive processes in the small intestine (mainly enzymatically digestion) and large intestine (exclusively fermentative digestion).

On the one hand, the fermentation of carbohydrates contributes to the patients' energy supply by providing short 
TABLE 1: Granula size and amylose content (\%) of starch sources used in this study.

\begin{tabular}{lccccc}
\hline & & Rice starch & Amaranth meal & Potato starch & Pea starch \\
\hline Granula size $(\mu \mathrm{m})^{*}$ & & $2-10$ & $0.5-2.0$ & $15-100$ & $10-45$ \\
\hline Granula size $(\mu \mathrm{m})^{* *}$ & & 4 & 1 & 10 & 15 \\
\hline \multirow{2}{*}{ Amylose content $(\%)$} & Raw & 6.3 & 1.53 & 8.68 & 20.5 \\
& Cooked & 11.1 & 1.86 & 18.3 & 27.0 \\
\hline
\end{tabular}

${ }^{*}$ According to literature [18-22].

${ }^{* *}$ Values used for calculating correlation between starch granula size and $\mathrm{pcD}$.

chain fatty acids $[13,14]$, but on the other hand there is also an increased gas production concomitantly [15], impairing the wellbeing of patients due to excessive intestinal formation of gas resulting in abdominal pain and flatulence $[14,16]$. Furthermore, there is also a higher risk of fermentative diarrhoea [17] due to the excessive influx of carbohydrates into the hindgut.

As observed in a former study, the botanical origin of the starch had a marked effect on praecaecal digestibility in PL-pigs [23], but in that study only raw starch sources were used which does not mimic the situation in human nutrition. Therefore, this study aimed to test potential effects of the botanical origin as well as thermal treatment (cooking) of the starch on praecaecal digestibility in minipigs with or without experimentally induced PEI.

The results of this study should contribute to optimising dietary recommendations for human patients suffering from PEI.

\section{Material and Methods}

All efforts were made to minimise both the stress for the individual animal and the numbers of animals used. The procedures used in this study were conducted in accordance with the German Animal Welfare Act and with the European Council Directive of 24 November 1986 (86/609/EEC) and were approved by the Ethics Committee on Animal Welfare of the Hannover District Government.

2.1. Animals. Altogether, 6 adult female minipigs, fitted with an ileocaecal reentrant fistula (according to the method described by Tabeling et al. [11]), were used for this study. In PL-pigs $(n=3)$, additionally, a ligation of the ductus pancreaticus accessorius was performed to induce the PEI experimentally. In all pigs activity of faecal chymotrypsin was measured (test kit purchased from Immundiagnostik AG, Wiesenstrasse 4, 64625 Bensheim, Germany, catalogue number K6990) and only minipigs with a chymotrypsin activity $<0.900 \mathrm{U} / \mathrm{g}$ faeces were defined and used as PL-pigs. The other minipigs $(n=3)$ with an intact pancreas served as controls (C). The body weight of the minipigs used in the present study was $37.0 \pm 2.50 \mathrm{~kg}(\mathrm{C})$ and $37.7 \pm 5.74 \mathrm{~kg}(\mathrm{PL})$.

2.2. Test Design. Starch of different botanical origin was chosen to include starch sources of different granula size in this study (Table 1).

The different starch sources were tested in a screening-test established by Becker [24]. Therefore, the terms "digestibility rate" or "coefficient of starch absorption" were replaced by rate of "praecaecal Disappearance" (pcD). The test diet (including the starch to be tested and $\mathrm{Cr}_{2} \mathrm{O}_{3}$ as a marker) was fed only once without any adaptation period and chyme collection was performed over $8 \mathrm{~h}$ after the first occurrence of the green colour of the chyme indicated the arrival of the test diet at the fistula at the terminal ileum. In PL-pigs enzyme replacement therapy with Creon was stopped at least three days before the trial started and no enzymes were given during the test. In the evening before the test started the pigs were fed only $400 \mathrm{~mL}$ of a liquid diet (ProvideXtra DRINK by Fresenius Kabi Deutschland $\mathrm{GmbH}$, Bad Homburg, Germany) to optimise gastric emptying and to avoid a carryover of nutrients of the diet from the previous evening into the test. A washout period of at least $48 \mathrm{~h}$ between two screening-tests was used to ensure a washout of $\mathrm{Cr}_{2} \mathrm{O}_{3}$ out of the praecaecal gastrointestinal tract. The different sources of starch were tested in a randomised order with every pig receiving all diets. For reasons of low palatability and incomplete feed intake one pig had to be replaced by another for the test diet containing raw amaranth.

2.3. Test Diet. The test meal consisted of $150 \mathrm{~g}$ of the starch to be tested, $25 \mathrm{~mL}$ of olive oil (Fa. Roth, Karlsruhe, Germany), $30 \mathrm{~g}$ of methylcellulose (Methocel, Sigma Aldrich Chemie, Germany), and $0.625 \mathrm{~g} \mathrm{Cr}_{2} \mathrm{O}_{3}$ (Sigma Aldrich Chemie, 98\% $\leq$ $50 \mu \mathrm{m})$. Isolated starch and test diets were analysed using standard methods according to Naumann and Bassler [25]. Starch content was measured polarimetrically while amylose content of the starch was measured enzymatically using a test kit (K-AMYL, Megazyme, Bray Co., Wicklow, Ireland).

Chemical composition of the test diets is described in Table 2. As no isolated amaranth starch was commercially available a whole-grain meal was used for this trial. Therefore, this test meal contained a lower starch content as the total amount of diet was identical (see Table 2). To test whether the lower starch content of amaranth affected values of $\mathrm{pcD}$, in addition, a higher amount of the raw amaranth whole-grain meal ( $212 \mathrm{~g}$ instead of $150 \mathrm{~g}$ ) was fed to reach a starch uptake comparable to the other diets.

Thermal treatment of starch was performed by cooking over 20 minutes. The amount of water was adapted to allow continuous stirring of the starch mash with amounts of water differing from 2.5 (amaranth) up to 5 litres (potato) per $\mathrm{kg}$ starch. After cooking, starch was dried by freeze drying (freeze dryer: alpha 1-4 LSC, Martin Christ, Gefriertrocknungsanlagen $\mathrm{GmbH}$, Osterode am Harz, Germany). 
TABLE 2: Nutrient concentration ( $\mathrm{g} / \mathrm{kg} \mathrm{DM})$ of the test diets containing different sources of starch (analysed values).

\begin{tabular}{lccccc}
\hline & $\begin{array}{c}\text { Crude } \\
\text { ash }\end{array}$ & $\begin{array}{c}\text { Crude } \\
\text { protein }\end{array}$ & $\begin{array}{c}\text { Crude } \\
\text { fat }\end{array}$ & Starch & Sugar \\
\hline Rice starch & & & & & \\
$\quad$ Raw & 7.73 & 3.29 & 140 & 672 & $<1$ \\
$\quad$ Cooked & 9.95 & 3.53 & 133 & 690 & 1.66 \\
Amaranth meal & & & & & \\
$\quad$ Raw & 23.4 & 107 & 190 & 431 & 11.7 \\
$\quad$ Cooked & 25.6 & 110 & 187 & 476 & 11.3 \\
Potato starch & & & & & \\
$\quad$ Raw & 7.52 & 2.25 & 131 & 605 & $<1$ \\
$\quad$ Cooked & 7.37 & 2.61 & 126 & 618 & 1.66 \\
Pea starch & & & & & \\
$\quad$ Raw & 7.69 & 3.40 & 126 & 683 & 1.20 \\
Cooked & 8.15 & 2.32 & 134 & 605 & 2.83 \\
\hline
\end{tabular}

2.4. Sampling. Ileal chyme was collected by opening the reentrant fistula, closing the caecal fistula with a cover containing a membrane, and fixing a flexible bin to the ileal fistula. These bins were emptied frequently and replaced by new ones. Water and electrolytes were substituted $(1 \mathrm{~mL}$ per gramme chyme collected) into the caecal fistula every two hours according to the method described by Tabeling et al. [11].

2.5. Sample Preparation and Analyses. Samples of ileal chyme were weighed and frozen immediately after collection, freeze-dried (freeze dryer: alpha 1-4 LSC, Martin Christ, Gefriertrocknungsanlagen $\mathrm{GmbH}$, Osterode am Harz, Germany), and analysed regarding dry matter and starch (polarimetrically) according to Naumann and Bassler [25]. $\mathrm{Cr}_{2} \mathrm{O}_{3}$ was determined according to the method of Petry and Rapp [26]. The pcD was calculated according to Becker [24] and Mößeler et al. [23].

Statistical analysis was performed using SAS version 9.31 (SAS Institute Inc., Cary, NC, USA). For testing the effects of botanical origin and thermal processing of the starch within one group of animals a paired $t$-test was used while for the comparison of the results of the control and PL-pigs an unpaired $t$-test was used. Significant effects of the group were stated when $P<0.05$.

\section{Results}

3.1. Effect of PEI on Praecaecal Disappearance Rate of Raw Starch. The pcD of starch was significantly reduced in the PLpigs compared to the controls for amaranth, potato starch, and pea starch. When raw rice starch was fed, there was also a large numerical difference regarding $\mathrm{pcD}$ between the controls and PL-pigs but due to high individual variation in the PL-pigs $(69.6 \pm 23.7)$ this difference reached no significance (see Figure 1).

3.2. Effect of PEI on Praecaecal Disappearance Rate of Thermal Treated Starch. The $\mathrm{pcD}$ of starch was significantly reduced

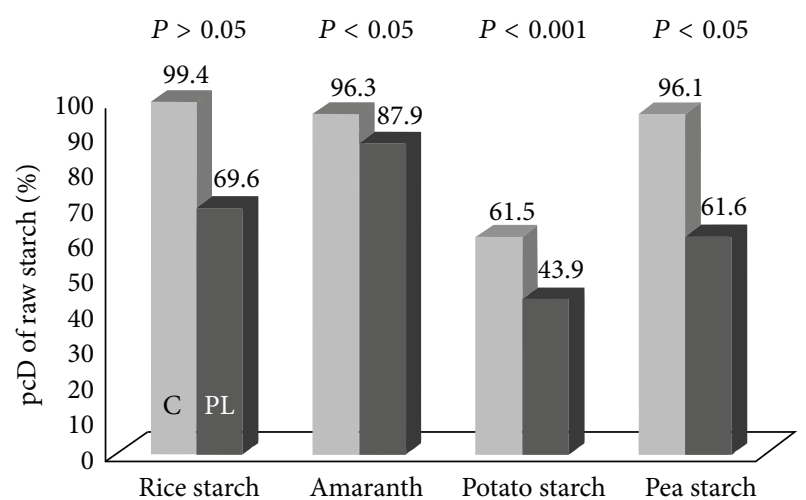

FIGURE 1: pcD of different sources of starch fed raw to control-pigs (C, light grey bars) and pancreatic duct ligated pigs (PL, grey bars).



Figure 2: pcD of different sources of starch fed after thermal treatment to control-pigs (C, light grey bars) and pancreatic duct ligated pigs (PL, grey bars).

in PL-pigs compared to controls for cooked amaranth, while there was no significant effect of PEI when rice starch, potato starch, and pea starch were fed (see Figure 2).

3.3. Effect of Botanical Origin of Starch. In C-pigs the $\mathrm{pcD}$ of raw starch was high in general $(>96 \%)$ but was significantly lower when raw potato starch was fed $(61.5 \%)$, while there was no significant effect of botanical origin when the different sources of starch were fed cooked, with values varying from 91 to $99 \%$ (see Table 3).

In PL-pigs feeding of the raw potato starch resulted in the lowest $\mathrm{pcD}$ with values $(43.9 \pm 2.71 \%)$ being significantly lower $(P<0.005)$ than $\mathrm{pcD}$ observed after feeding amaranth $(87.9 \pm 3.50)$. When cooked starch was fed, the values differed between $87.5 \%$ (amaranth) and 91.7\% (rice starch).

3.4. Effect of Thermal Processing. In both groups, cooking of starch resulted in a significant increase $(P<0.05)$ of $\mathrm{pcD}$ of potato starch. While thermal treatment did not affect $\mathrm{pcD}$ of starch in controls (except for potato starch), in the group PL-pigs, cooking of starch resulted in a significant increase in $\mathrm{pcD}$ for all sources of starch tested except for amaranth. It is worth mentioning that variation regarding $\mathrm{pcD}$ was very 
TABLE 3: PcD of starch (\%) in control- and PL-pigs when starch of different botanical origin was used either raw or cooked.

\begin{tabular}{lcccc}
\hline & \multicolumn{2}{c}{ Control-pigs } & \multicolumn{2}{c}{ PL-pigs } \\
& Raw & Cooked & $69.6 \pm 23.7^{* \mathrm{ab}}$ & \\
\hline Rice starch & $99.4 \pm 0.372^{* \mathrm{a}}$ & $99.4 \pm 0.559^{\mathrm{a} *}$ & $87.9 \pm 3.50^{* \mathrm{a}}$ & $81.7 \pm 7.01^{\# \mathrm{ab}}$ \\
Amaranth & $96.3 \pm 3.07^{* \mathrm{a}}$ & $96.0 \pm 2.19^{* \mathrm{a}}$ & $43.9 \pm 2.71^{* \mathrm{~b}}$ & $87.5 \pm 3.08^{* \mathrm{a}}$ \\
Potato starch & $61.5 \pm 1.90^{* \mathrm{~b}}$ & $90.9 \pm 9.61^{\mathrm{aa}}$ & $61.6 \pm 20.6^{* \mathrm{ab}}$ & $90.2 \pm 4.82^{\# \mathrm{ab}}$ \\
Pea starch & $96.1 \pm 3.30^{* \mathrm{a}}$ & $92.3 \pm 4.65^{* \mathrm{a}}$ & $91.0 \pm 2.37^{\# \mathrm{~b}}$ \\
\hline
\end{tabular}

Different symbols mark significant effects of thermal treatment within one group of animals when starch of one botanical source was fed $(P<0.05)$.

Different letters mark significant effects of botanical origin within one group of animals when starch was fed either raw or cooked (within one row) $(P<0.05)$.

high in the PL-pigs for raw rice starch and raw pea starch. When these sources of starch were fed cooked the variation was much lower (see Table 3).

To check whether the high pcD of the starch from raw amaranth resulted from the lower starch content, additionally, a test meal with a higher amount of raw amaranth was fed to equalise the amount of starch per test meal. Neither in the C-pigs $(97.5 \pm 0.855)$ nor in the PL-pigs $(81.3 \pm 5.12)$ did the increased amount of the raw amaranth per meal $(212 \mathrm{~g} / \mathrm{meal})$ have any effect on the $\mathrm{pcD}$ compared to the values observed after feeding $150 \mathrm{~g}$ of amaranth per meal.

\section{Discussion}

As determining praecaecal digestibility is of greatest relevance to evaluate the nutritive value of starch [27], use of fistulated animals is an established way to investigate questions dealing with this topic. There are many studies dealing with the effects of different types of cereals and further processing on digestibility of starch or glycemic index in healthy individuals $[28,29]$. The term resistant starch is used to describe the starch escaping from enzymatic digestion in the small intestine [30].

The part of starch being digested and absorbed in praecaecal parts of the GIT is of special interest as postileal degradation of resistant starch is only performed by intestinal microflora, having beneficial effects on colonic health by degradation to butyric acid [31] but also resulting in an increased gas production (causing energy losses and meteorism increasing the risk for abdominal pain). Therefore, a high praecaecal digestibility of starch is intended in general, if no probiotic effects of resistant starch or a low glycemic index [28] are the focus of interest. In patients with PEI the lack of pancreatic amylases can be compensated to some extent by salivary amylases and digestive enzymes of the brush border membrane [32]. Nonetheless, it has to be considered that, especially in case of small intestinal bacterial overgrowth [33, 34], starch is also partly digested by microbial degradation in the small intestine resulting in increased intestinal gas production which can be used for diagnostic tests such as the hydrogen exhalation test [12].

The digestibility of starch is influenced by botanical origin [35] with content of amylose being one factor [29, 35]. The higher $\mathrm{pcD}$ of starch with low amylose content was confirmed in both groups of animals, but in both groups the $\mathrm{pcD}$ of raw pea starch was higher than for potato starch, although the amylose content in the pea starch was highest.
Furthermore, the digestibility was affected by granula size of the starch. The $\mathrm{pcD}$ of starch was lower for starch sources with larger granula size as a result of lower surface area [21]. Although the strength of this finding is limited due to the low number of starch sources used in this study this finding seems noteworthy and further sources of starch should be tested to verify this hypothesis. The very high $\mathrm{pcD}$ of amaranth starch is assumed to result from the very small granula size and the low amylose content of this starch. The correlation between granula size (taken from literature) (see Table 1) and $\mathrm{pcD}$ of different sources of starch is slight (smallest particle size resulting in highest $\mathrm{pcD}$ ). It can be assumed that the higher surface area allows a better degradation and respectively digestion by extrapancreatic amylases; furthermore porosity of starch is another relevant aspect that needs to be taken into account as it might affect access of enzymes to the granule interior [36]. Interestingly in C-pigs three of four sources of starch were digested almost completely with no effect of granula size while the data of PL-pigs were best visualised by a logarithmic trend line (see Figure 3 ). As the surface area of a sphere is $4 \pi r^{2}$ but the volume is $4 / 3 \pi r^{3}$ the right hand curve is consistent with a role for particle size determining the surface area for enzymatic attack.

Cooking starch has been well known for a very long time and is a traditional method to increase praecaecal digestibility of starch and to reduce negative side effects of fermentation. It is well accepted that necessity of thermal processing is dependent on the source of starch; for example, raw potato starch (high proportion of resistant starch) is not adequate for human nutrition while most grains (breakfast cereals) can be used as food without thermal processing in healthy individuals.

The results of this study are of special interest for dietary treatment of human patients with PEI. Adult healthy minipigs are able to digest starch of different origin quite efficiently praecaecally; even the starch was not heat treated. Only raw potato starch was digested to a lower extent $(P<$ 0.05) in C-pigs. This finding tallies well with that of Rerat [37] and is presumably due to the high content of resistant starch in potatoes [38]. In PL-pigs $\mathrm{pcD}$ of raw starch was distinctly reduced in comparison to C-pigs for most sources of starch. In patients with PEI raw sources of starch with a low pcD should be avoided to minimise the bacterial fermentation processes in the hindgut. Although treatment of PEI mainly focuses on lipase substitution, the widespread use of multienzyme products provides amylases as well as improving praecaecal starch digestibility. However, in case 


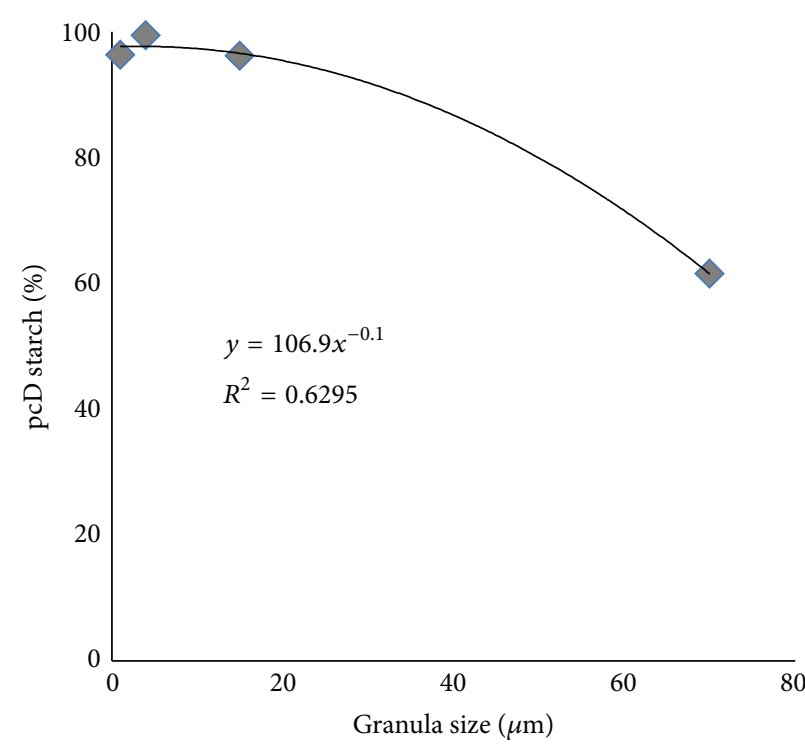

(a)

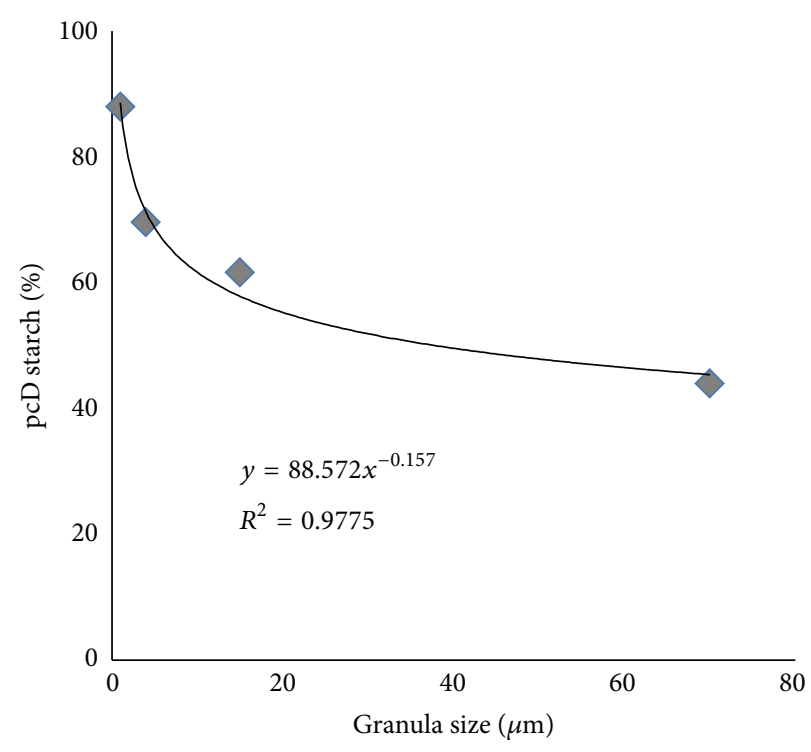

(b)

FIGURE 3: pcD of raw starch (\%) in control-pigs (a) and PL-pigs (b) plotted against the granula size of the starch used (data taken from literature).

of use of monoenzyme products (isolated lipase) or when a diet low in fat is consumed (and therefore enzyme dosage is low when enzymes are dosed according to the amount of ingested fat [39]) there might be a lack of amylolytic enzymes. The optimisation of the praecaecal digestibility of starch is very important as resistant starch not being digested praecaecally is fermented almost completely in the hindgut and might result in massive intraintestinal gas production. In in vitro tests fermentation of $1 \mathrm{~g}$ of starch in ileal chyme of PL-pigs resulted in a production of up to $160 \mathrm{~mL}$ of gas [15]. Although the consumed starch is quite often cooked or processed thermally in human nutrition [40], there is food (e.g., breakfast cereals) that is not processed. Therefore, the results observed here are of interest for patients with PEI. Particularly as there is a trend for raw vegetarian food in some parts of the population as "health food" this might be relevant. Using raw foodstuffs containing starch in the nutrition of PEI patients should be done carefully and on an individual basis of tolerance.

The screening-test model used in this study seems to be an interesting and suitable method not only for testing pancreatic enzyme preparations in vivo [41] but also for screening different foodstuffs.

This study clearly underlines the need for botanic characterisation of starch in nutrition and dietetics. The fact that ranking of starch pcD differed between C- and PL-pigs emphasises the need for investigations on specific animal models or patients when trying to optimise diet formulation for special dietetic purposes.

\section{Conflict of Interests}

The authors declare that there is no conflict of interests regarding the publication of this paper.

\section{Authors' Contribution}

Conception and design were the responsibility of Anne Mößeler and Josef Kamphues. Provision of study materials or patients was the responsibility of Anne Mößeler, Josef Kamphues, and Sandra Vagt. Collection and assembly of data were done by Sandra Vagt. Data analysis and interpretation were the responsibility of Sandra Vagt, Anne Mößeler, and Martin Beyerbach. Paper writing was performed by Anne Mößeler. Final approval of paper was by all authors.

\section{References}

[1] A. R. Imondi, R. P. Stradley, and R. Wolgemuth, "Enzyme replacement therapy in the pancreatic duct ligated swine," Proceedings of the Society for Experimental Biology and Medicine, vol. 141, no. 1, pp. 367-372, 1972.

[2] J. Abello, X. Pascaud, C. Simoes-Nunes, J. C. Cuber, J. L. Junien, and C. Roze, "Total pancreatic insufficiency in pigs: a model to study intestinal enzymes and plasma levels of digestive hormones after pancreatic supplementation by a whole pancreas preparation," Pancreas, vol. 4, no. 5, pp. 556-564, 1989.

[3] P. C. Gregory, R. Tabeling, and J. Kamphues, "Growth and digestion in pancreatic duct ligated pigs. Effect of enzyme supplementation," in Biology of the Pancreas in Growing Animals, Z. Pierzynowski, Ed., pp. 381-394, Elsevier Science B.V., 1999.

[4] E. Kammlott, J. Karthoff, K. Stemme, P. Gregory, and J. Kamphues, "Experiments to optimize enzyme substitution therapy in pancreatic duct-ligated pigs," Journal of Animal Physiology and Animal Nutrition, vol. 89, no. 3-6, pp. 105-108, 2005.

[5] S. Rengman, O. Fedkiv, J. Botermans, J. Svendsen, B. Weström, and S. Pierzynowski, "An elemental diet fed, enteral or parenteral, does not support growth in young pigs with exocrine pancreatic insufficiency," Clinical Nutrition, vol. 28, no. 3, pp. 325-330, 2009. 
[6] R. D. Mackie, A. S. Levine, and M. D. Levitt, "Malabsorption of starch in pancreatic insufficiency," Gastroenterology, vol. 80, p. 1220,1981 , abstract.

[7] S. D. Ladas, K. Giorgiotis, and S. A. Raptis, "Complex carbohydrate malabsorption in exocrine pancreatic insufficiency," Gut, vol. 34, no. 7, pp. 984-987, 1993.

[8] P. Layer, A. R. Zinsmeister, and E. P. DiMagno, "Effect of decreasing intraluminal amylase activity on starch digestion and postprandial gastrointestinal function in humans," Gastroenterology, vol. 91, no. 1, pp. 41-48, 1986.

[9] J.-M. Löhr, Exokrine Pankreasinsuffizienz, UNI-MED Verlag AG, Bremen, Germany, 2001.

[10] A. Mößeler, R. Tabeling, P. C. Gregory, and J. Kamphues, "Compensatory digestion of fat, protein and starch (rates and amounts) in the large intestine of minipigs in case of reduced precaecal digestion due to pancreatic duct ligation-a short review," Livestock Science, vol. 109, no. 1-3, pp. 50-52, 2007.

[11] R. Tabeling, P. Gregory, and J. Kamphues, "Studies on nutrient digestibilities (pre-caecal and total) in pancreatic duct-ligated pigs and the effects of enzyme substitution," Journal of Animal Physiology and Animal Nutrition, vol. 82, no. 5, pp. 251-263, 1999.

[12] J. Keller, A. Franke, M. Storr, F. Wiedbrauck, and J. Schirra, "Clinically relevant breath tests in gastroenterological diagnostics-recommendations of the german society for neurogastroenterology and motility as well as the german society for digestive and metabolic diseases," Zeitschrift fur Gastroenterologie, vol. 43, no. 9, pp. 1071-1090, 2005.

[13] N. I. McNeil, J. H. Cummings, and W. P. T. James, "Short chain fatty acid absorption by the human large intestine," Gut, vol. 19, no. 9, pp. 819-822, 1978.

[14] J. H. Cummings, "Fermentation in the human large intestine: evidence and implications for health," The Lancet, vol. 1, no. 8335, pp. 1206-1209, 1983.

[15] S. Vagt, In-vivo and in-vitro investigations on prececal starch digestion (related to source of starch and thermal treatment) in pancreatic duct ligated minipigs-used as a model for human exocrine pancreatic insufficiency [Doctoral thesis], University of Veterinary Medicine, Hannover, Germany, 2014, http://elib.tiho-hannover.de/dissertations/vagts_ss14.pdf.

[16] J. Keller, A. A. Aghdassi, M. M. Lerch, J. V. Mayerle, and P. Layer, "Tests of pancreatic exocrine function-clinical significance in pancreatic and non-pancreatic disorders," Best Practice and Research: Clinical Gastroenterology, vol. 23, no. 3, pp. 425-439, 2009.

[17] H. F. Hammer, K. D. Fine, C. A. Santa Ana, J. L. Porter, L. R. Schiller, and J. S. Fordtran, "Carbohydrate malabsorption. Its measurement and its contribution to diarrhea," The Journal of Clinical Investigation, vol. 86, no. 6, pp. 1936-1944, 1990.

[18] J. L. Jane, L. Shen, L. Wang, and C. C. Maningat, "Preparation and properties of small-particle cornstarch," Cereal Chemistry, vol. 69, pp. 280-283, 1992.

[19] J.-L. Jane, T. Kasemsuwan, S. Leas, H. Zobel, and J. F. Robyt, "Anthology of starch granule morphology by scanning electron microscopy," Starch, vol. 46, no. 4, pp. 121-129, 1994.

[20] G. H. Zheng and F. W. Sosulski, "Physicochemical properties of small granule starches," in Proceedings of the AACC Annual Meeting, San Diego, Calif, USA, 1997.

[21] R. F. Tester, J. Karkalas, and X. Qi, "Starch-composition, fine structure and architecture," Journal of Cereal Science, vol. 39, no. 2, pp. 151-165, 2004.
[22] Cargillfoods, 2014, http://www.cargillfoods.com/na/en/products/ starches-derivatives/molecular-structure/index.jsp.

[23] A. Mößeler, N. Kramer, C. Becker, P. C. Gregory, and J. Kamphues, "Prececal digestibility of various sources of starch in minipigs with or without experimentally induced exocrine pancreatic insufficiency," Journal of Animal Science, vol. 90, supplement 4, pp. 83-85, 2012.

[24] C. Becker, Development of a screening-test to assess activity of substituted proteolytic and amylolytic enzymes by using pancreatic duct ligated minipigs [Doctoral thesis], University of Veterinary Medicine, Hanover, Germany, 2005, http://elib.tihohannover.de/dissertations/beckerc_ws05.html.

[25] C. Naumann and R. Bassler, Methoden der landwirtschaftlichen Forschungs- und Untersuchungsanstalt, Biochemische Untersuchung von Futtermitteln. Methodenbuch III (einschließlich der achten Ergänzungen), VDLUFA, Darmstadt, Germany, 2012.

[26] H. Petry and W. Rapp, "Zur Problematik der Chromoxidbestimmung in Verdauungsversuchen," Zeitschrift für Tierphysiologie Tierernährung und Futtermittelkunde, vol. 27, pp. 181-189, 1970.

[27] J. Kamphues, "Effekte der EPI auf Verdauungsprozesse im Dünn- und Dickdarm von Schweinen," in Wissenschaftliches Symposium am 06.06.2013 in Hannover: Exokrine Pankreasinsuffizienz (EPI) - Neues aus Forschung und Praxis, A. Mößeler, U. Seidler, and J. Kamphues, Eds., pp. 20-31, 2013.

[28] D. J. A. Jenkins, T. M. S. Wolever, and A. L. Jenkins, "Starchy foods and glycemic index," Diabetes Care, vol. 11, no. 2, pp. 149$159,1988$.

[29] A. Åkerberg, H. Liljeberg, and I. Björck, "Effects of amylose/amylopectin ratio and baking conditions on resistant starch formation and glycaemic indices," Journal of Cereal Science, vol. 28, no. 1, pp. 71-80, 1998.

[30] H. N. Englyst, S. M. Kingman, and J. H. Cummings, "Classification and measurement of nutritionally important starch fractions," European Journal of Clinical Nutrition, vol. 46, supplement 2, pp. S33-S50, 1992.

[31] W. E. W. Roediger, "Role of anaerobic bacteria in the metabolic welfare of the colonic mucosa in man," Gut, vol. 21, no. 9, pp. 793-798, 1980.

[32] Z. Ao, R. Quezada-Calvillo, L. Sim et al., "Evidence of native starch degradation with human small intestinal maltaseglucoamylase (recombinant)," FEBS Letters, vol. 581, no. 13, pp. 2381-2388, 2007.

[33] A. Parodi, E. C. Lauritano, G. Nardone, L. Fontana, V. Savarino, and A. Gasbarrini, "Small intestinal bacterial overgrowth," Digestive and Liver Disease Supplements, vol. 3, no. 2, pp. 4449, 2009.

[34] J. Bures, J. Cyrany, D. Kohoutova et al., "Small intestinal bacterial overgrowth syndrome," World Journal of Gastroenterology, vol. 16, no. 24, pp. 2978-2990, 2010.

[35] J. W. Cone and M. G. E. Wolters, "Some properties and degradability of isolated starch granules," Starch, vol. 42, no. 8, pp. 298-301, 1990.

[36] J. E. Fannon, R. J. Hauber, and J. N. BeMiller, "Surface pores of starch granules," Cereal Chemistry, vol. 69, no. 3, pp. 284-288, 1992.

[37] A. Rerat, "Verdauung und Stoffwechsel von Kohlenhydraten und Proteinen im Dickdarm von Schweinen," Übersichten zur Tierernährung, vol. 9, pp. 177-232, 1981.

[38] M. D. Morales, A. Escarpa, and M. C. Gonzalez, "Simultaneous determination of resistant and digestible starch in foods and food products," Starch, vol. 49, no. 11, pp. 448-453, 1997. 
[39] M. Stern, H. Ellemunter, B. Palm, H. G. Posselt, and C. Smaczny, "(Cystische Fibrose): Ernährung und exokrine Pankreasinsuffizienz.S1-Leitlinie der Gesellschaft für Pädiatrische Gastroenterologie und Ernährung (GPGE)," 2011, http:// www.awmf.org/uploads/tx_szleitlinien/068-0201_S1_Mukoviszidose_Ernährung_exokrine_Pankreasinsuffizienz_2011-05.pdf.

[40] D. R. Lineback and E. Wongsrikasem, "Gelatinization of starch in baked products," Journal of Food Science, vol. 45, no. 1, pp. 71-74, 1980.

[41] R. Ishihara, P. Gregory, H. F. Koch et al., "Comparison study of pharmacological efficacy of pancreatic digestive enzyme replacement (LipaCreon Granules) and of digestive enzymes (Berizym Combination Granules and Excelase Combination Granules) on digestibility of fat, protein and starch in a Minipig model of pancreatic exocrine insufficiency (in vivo)," Journal of New Remedies \& Clinics, vol. 61, no. 5, pp. 1044-1053, 2012. 


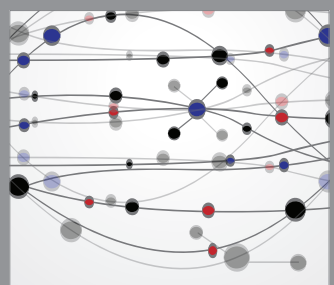

The Scientific World Journal
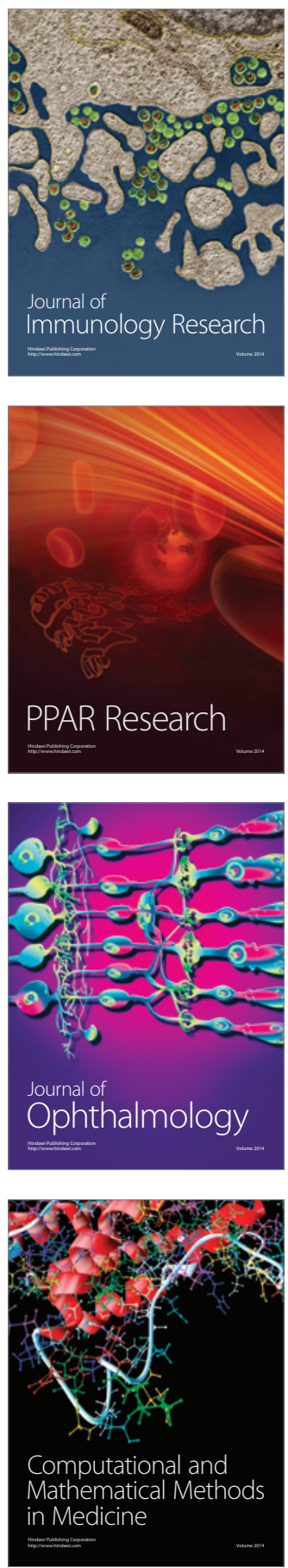

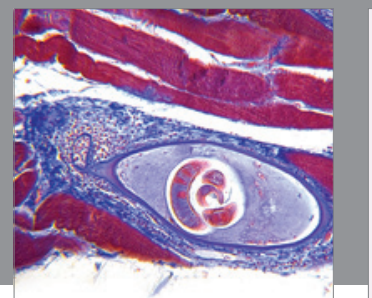

Gastroenterology

Research and Practice
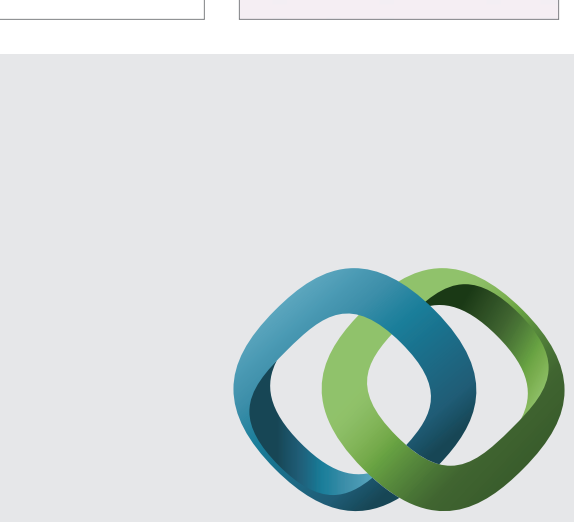

\section{Hindawi}

Submit your manuscripts at

http://www.hindawi.com
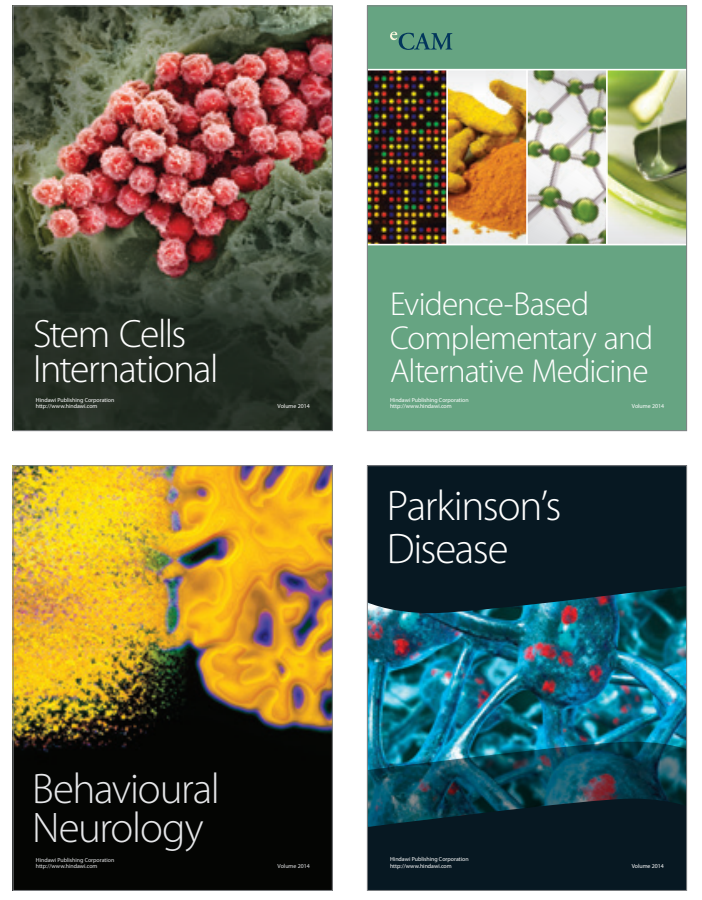
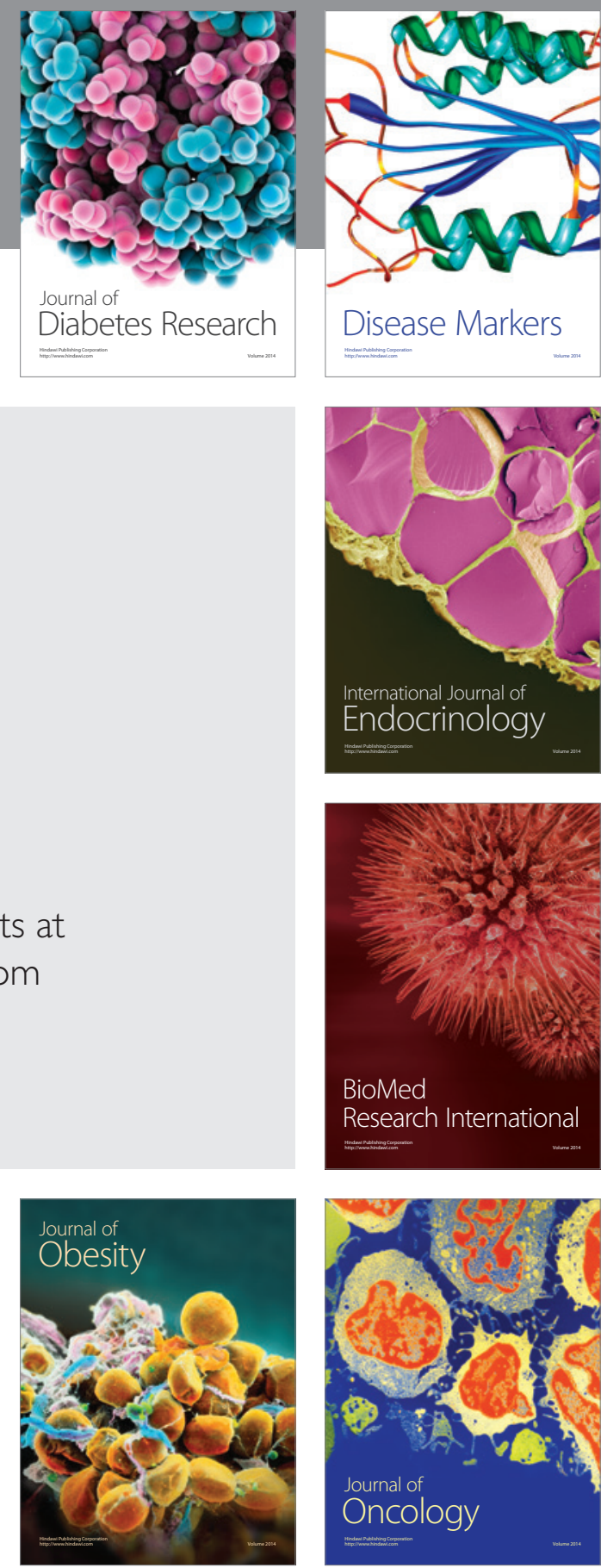

Disease Markers
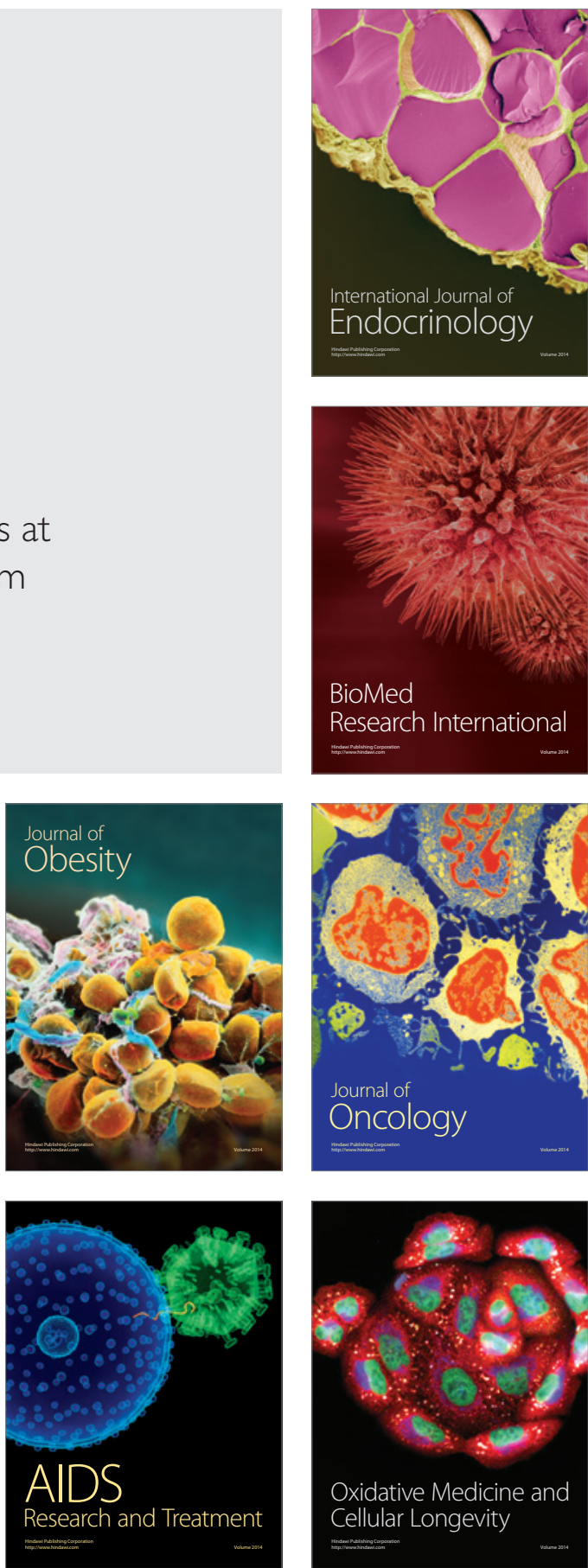